\title{
INTEGRATED FLOOD RISK ANALYSIS FOR EXTREME STORM SURGES (XTREMRISK)
}

\author{
Andreas Burzel ${ }^{1}$, Dilani Dassanayake ${ }^{1}$, Marie Naulin ${ }^{1}$, Andreas Kortenhaus ${ }^{1}$, \\ Hocine Oumeraci ${ }^{1}$, Thomas Wahl' ${ }^{2}$, Christoph Mudersbach ${ }^{2}$, Jürgen Jensen², \\ Gabriele Gönnert ${ }^{3}$, Kristina Sossidi ${ }^{3}$, Gehad Ujeyl ${ }^{4}$, Erik Pasche $^{4}$
}

\begin{abstract}
Extreme storm surges have frequently led to major damages also along the German coastline. The joint research project 'XtremRisK' was initiated to improve the understanding of risk-related issues due to extreme storm surges and to quantify the flood risk for two pilot sites at the open coast and in an estuarine area under present and future climate scenarios. In this context, an integrated flood risk analysis is performed based on the source-pathway-receptor concept under consideration of possible tangible and intangible losses. This paper describes the structure of the project, the methodology of the subprojects, and first results. Moreover, integration approaches are discussed. The results of 'XtremRisK' will be used to propose flood risk mitigation measures for the prospective end-users.
\end{abstract}

Keywords: integrated flood risk analysis, source-pathway-receptor concept, storm surge, intangible flood damages

\section{INTRODUCTION}

In the past, storm surges have frequently led to major damages also along the German coastline. Responsible authorities accomplished considerable efforts in order to reduce and prevent flood damages. However, due to expected climate change (IPCC 2007) and increasing frequencies of storm surges, it may be expected that storm surge hazards will significantly increase in the coming decades. Hence, it is urgently required to develop reliable assessment and mitigation tools and further improve mitigation measures under sustainability aspects.

Therefore, the joint research project 'XtremRisK' (Extreme Storm Surges at Open Coasts and Estuarine Areas - Risk Assessment and Mitigation under Climate Change Aspects) was initiated in 2008 (Oumeraci et al. 2009). The project is funded by the German Federal Ministry of Education and Research (BMBF) with a duration of 4 years.

XtremRisK aims to improve the understanding of extreme storm surge predictions, including the joint probability of extreme water levels and sea states. It will also provide tools to exemplarily quantify the overall flood risk under present and future climate change conditions for an open coast (pilot site Sylt Island) and a megacity in an estuarine area (pilot site Hamburg), respectively. Future conditions in 2100 under consideration of the impacts due to climate change are described and analysed by means of scenarios.

The XtremRisK project brings together scientists from different German universities (Braunschweig, Siegen, Hamburg) as well as from the Agency of Roads, Bridges and Waters in Hamburg. The end-users of the prospective results for Hamburg (Hamburg Port Authority, Agency of Roads, Bridges and Waters Hamburg) and Sylt Island (Schleswig-Holstein Agency for Coastal Defence, National Park and Marine Conservation) are also involved as cooperative partners. Moreover, there is a close cooperation with other ongoing national and international research projects.

The paper provides an overview of the XtremRisK project and its background, describes the methodology, and discusses some of the results obtained in the first year of the project. The paper focuses on the integrated risk analysis for the flood risk in the pilot site Hamburg-Wilhelmsburg. Moreover, the consideration of intangible damages for the integrated flood risk analysis will be described.

At first, the pilot site Hamburg-Wilhelmsburg is introduced. Afterwards, the methodology based on the source-pathway-receptor concept (as described in Oumeraci 2004) is briefly described. Then, first results for the pilot site Hamburg-Wilhelmsburg are discussed. Finally, a summary with future prospects is provided.

\footnotetext{
${ }^{1}$ Technische Universität Braunschweig, Leichtweiß-Institute for Hydraulic Engineering and Water Resources, Department of Hydromechanics and Coastal Engineering, Beethovenstraße 51a, 38106 Braunschweig (Germany) contact author: a.burzel@tu-braunschweig.de

${ }^{2}$ Research Institute for Water and Environment, University of Siegen, Siegen (Germany)

${ }^{3}$ Agency of Roads, Bridges and Waters, Hamburg (Germany)

${ }^{4}$ Department of River and Coastal Engineering, Hamburg University of Technology (TUHH), Hamburg (Germany)
} 


\section{PILOT SITES}

As mentioned, two pilot sites in Germany (Figure 1) were selected in order to exemplarily quantify the potential subsequent damages and the overall flood risk for a megacity in an estuarine area and an island at the open coast, respectively. In close collaboration with the responsible authorities, for both pilot sites flood risk mitigation measures will be proposed.

However, the methods to be developed in XtremRisK will be generic enough to be applied to other coastal areas at risk. Worldwide, risk is permanently increasing in coastal zones and estuarine regions, which are favoured settlement and economy areas. Moreover, coastal areas are of highest ecological value, though these ecosystems are extremely endangered (MEA 2005):

- $\quad$ The expected climate change will lead to increased frequencies of storm surges (Woth 2005).

- Accelerated urbanisation in coastal zones and world population growth result in increased vulnerability (Schwartz 2005).

- $\quad$ Rising economic wealth will cause increased consequences in coastal zones in the future.

- Significant degradation of coastal zones ecosystems, which are of highest value for flood defences, food supply and recreation, are considerably weakened (Oumeraci 2004).

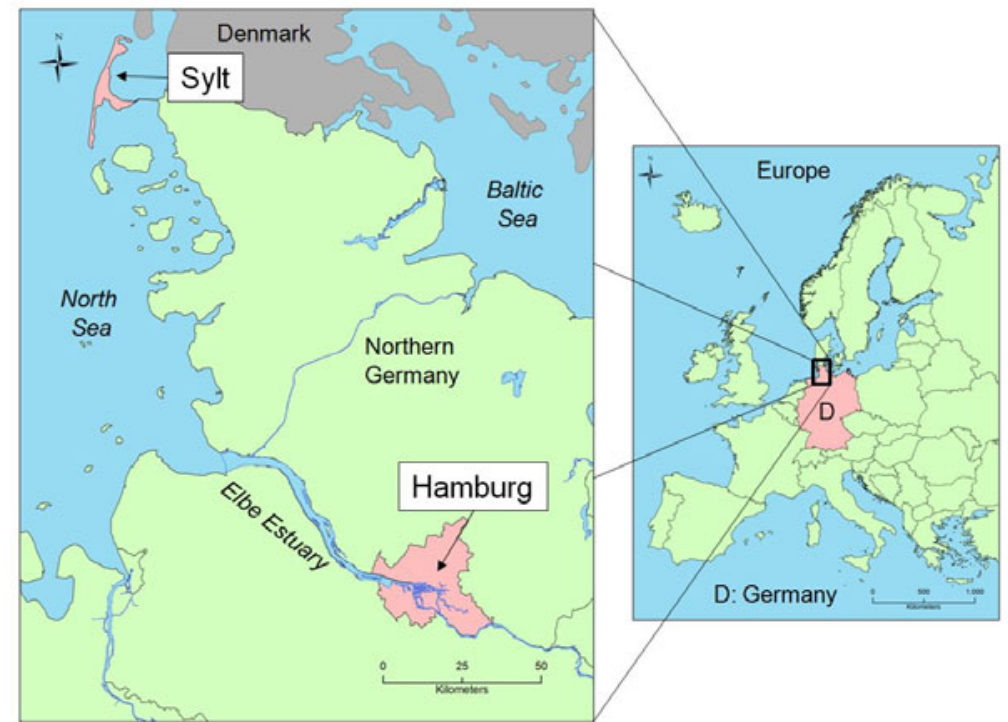

Figure 1. Location of pilot sites Hamburg and Sylt Island (Naulin et al. 2010).

The city of Hamburg is the second largest city in Germany with about 1.8 million inhabitants. The city is a centre for trade, transportation and services and one of the most important industrial sites in Germany. In addition, the port of Hamburg is the largest seaport of Germany.

Hamburg is located $100 \mathrm{~km}$ upstream of the Elbe estuary. There is a strong influence of the tidal dynamics of the North Sea with a mean high tide in Hamburg of $2.1 \mathrm{~m}$ above Normal Null (NN, datum for water level in Germany) (see Naulin et al. 2010). In the past, Hamburg was affected by extreme storm surges. In 1962, a storm surge caused 315 fatalities and considerable damages (Figure 2). Even though a more extreme storm surge with the highest observed water level in Hamburg of $6.45 \mathrm{~m} \mathrm{NN}$ occurred in 1976, the storm surge caused no fatalities due to an improved flood defence system.

Furthermore, the Island of Sylt was selected as a pilot site at the open coast. Sylt Island is particularly known for tourism, recreation and its ecosystems. In contrast, sea state and storm surges, among other factors, permanently cause erosion of beaches and dunes. However, the analysis of flood risk on Sylt Island will be discussed in a forthcoming paper. 
a)

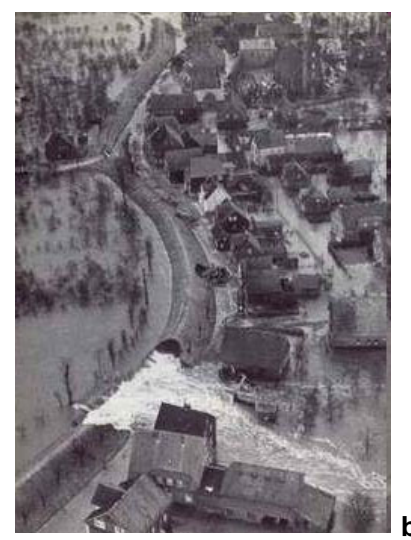

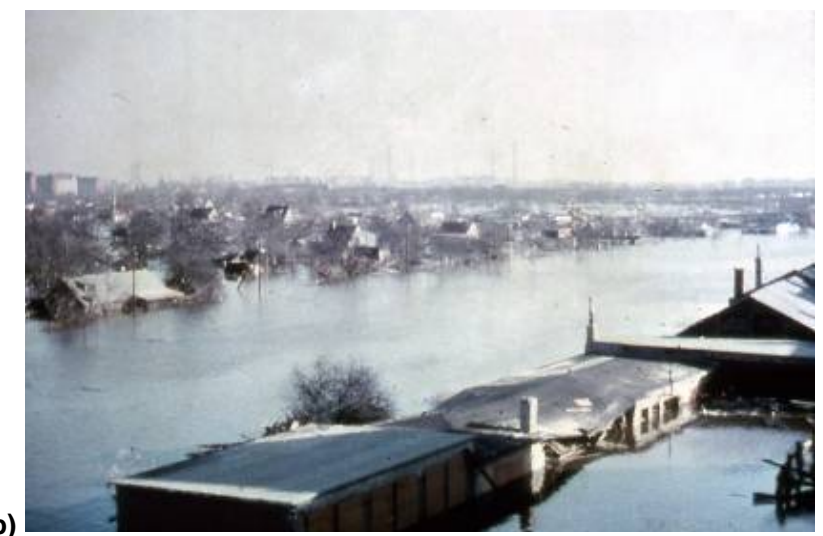

Within Hamburg, the quarter Hamburg-Wilhelmsburg is investigated in detail. In the following sections, the analysis and results with respect to this area will be described.

The quarter Hamburg-Wilhelmsburg is located on the Elbe River Island together with the quarters Veddel, Kleiner Grasbrook and Steinwerder (Figure 3). The island is surrounded by the Northern and Southern Elbe River branches. The overall area of the Elbe River Island is $50 \mathrm{~km}^{2}$. With an area of $35 \mathrm{~km}^{2}$, Hamburg-Wilhelmsburg is the largest quarter of Hamburg (Statistik Nord 2009).

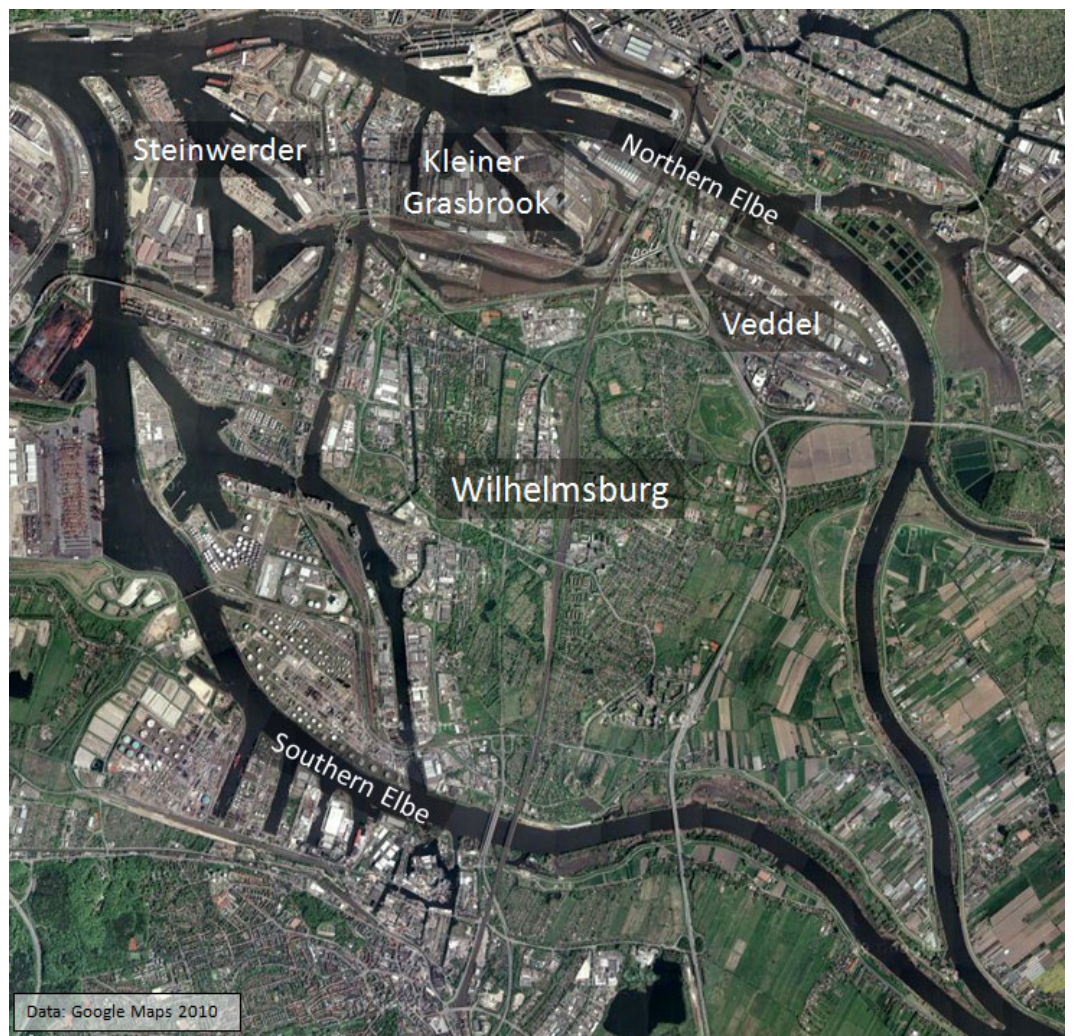

Figure 3. Satellite image of the Elbe River Island with districts, Northern and Southern Elbe River branches.

Most areas on the Elbe River Island have an elevation between $0 \mathrm{~m} \mathrm{NN}$ and $3 \mathrm{~m}$ NN. HamburgWilhelmsburg is protected by a flood defence ring of dikes and two flood protection walls with an overall length of $24 \mathrm{~km}$ (Figure 4) and heights varying from $7.80 \mathrm{~m}$ NN to $8.35 \mathrm{~m}$ NN. Approximately 50,000 inhabitants are living here, i.e. 1,400 inhabitants per $\mathrm{km}^{2}$ (Statistik Nord 2009). Most of the residential areas (about $15 \mathrm{~km}^{2}$ in total) are located in flood prone areas. 


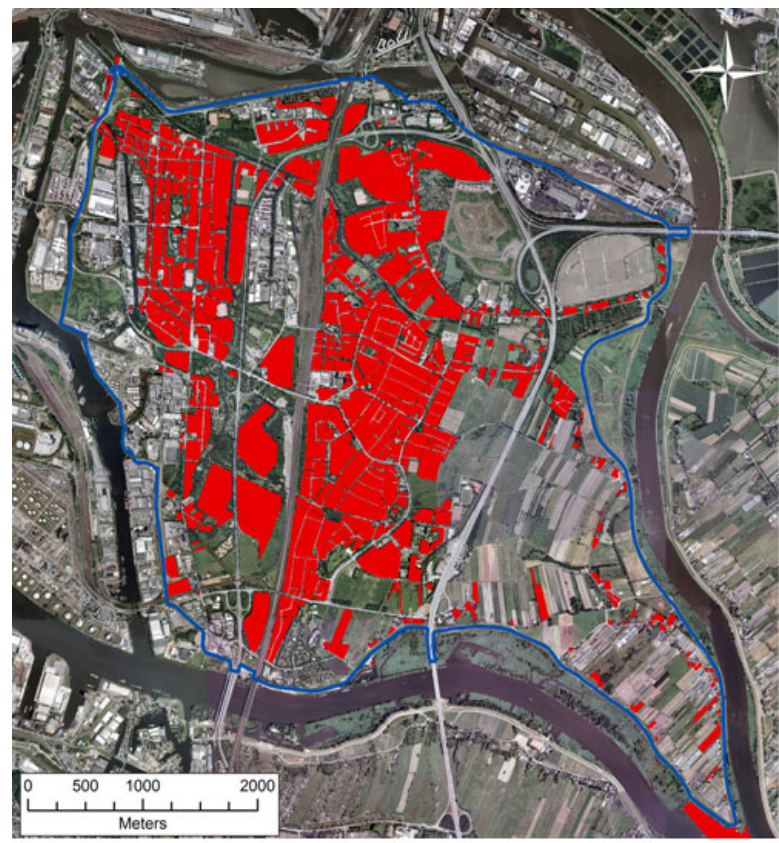

Data: Agency of Geo-Information and Surveying Hamburg, 2009

\section{Legend}

- Flood Protection Ring - ResidentialArea

Figure 4. Pilot site Hamburg-Wilhelmsburg with dike line and residential areas.

\section{METHODOLOGY}

In XtremRisK, the flood risk $R_{f}$ is defined as the combination of the probability of flooding $P_{f}$ and the expected damages $D$. For the integrated risk analysis, a source-pathway-receptor concept is used (see Oumeraci 2004), which was successfully applied in the European research project FLOODsite.

The integrated risk analysis comprises the investigation of largest physically possible storm surges (risk sources), coastal defence failure probabilities and related flooding probabilities (risk pathways), the estimation of consequences due to flooding by inundation and damage modelling (risk receptors) and the integration of all results as shown in the flow chart in Figure 5.

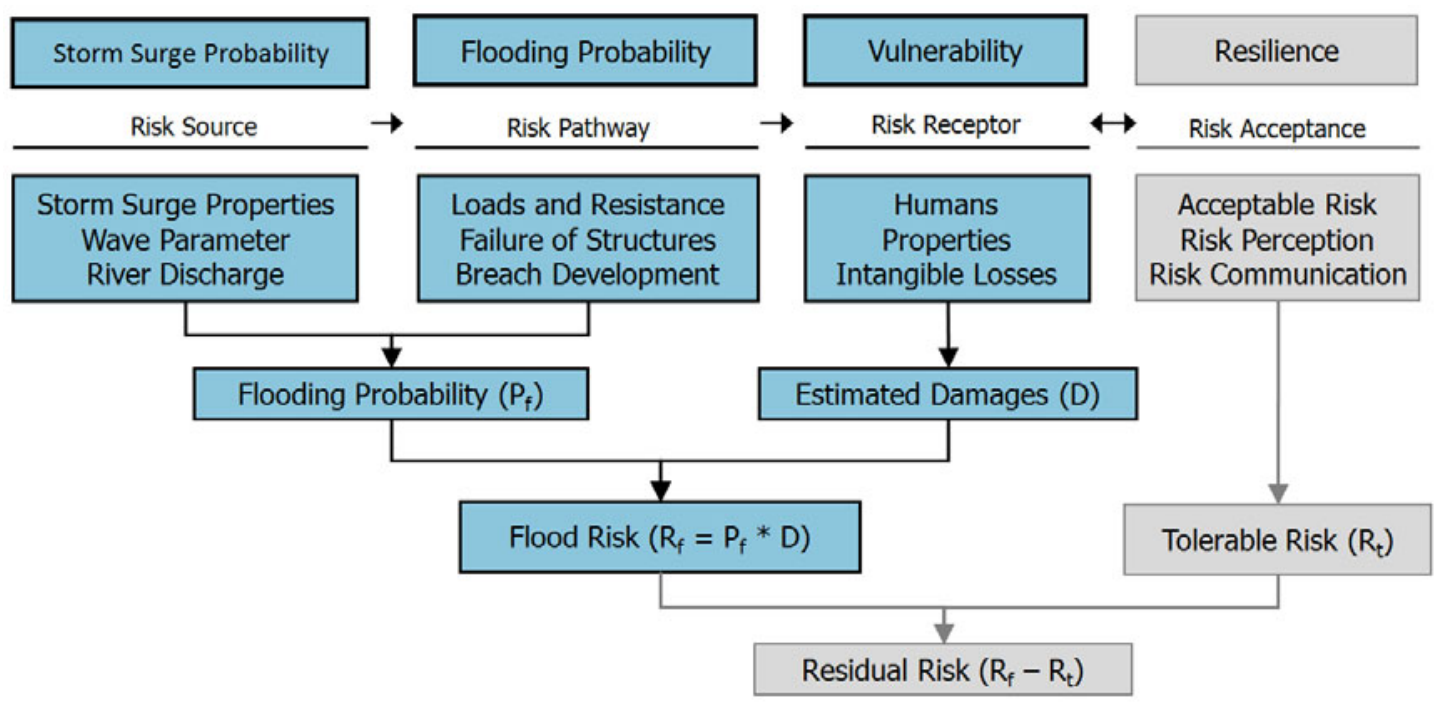

Figure 5. Integrated flood risk analysis flow chart.

Based on the concept summarised in Figure 5, XtremRisK consists of four subprojects (SP):

- $\quad$ SP1: Extreme storm surges (risk sources),

- SP2: Loading, breaching and breach development of flood defence structures (risk pathways),

- SP3: Damage assessment and evaluation (risk receptors),

- $\quad$ SP4: Risk analysis, risk evaluation and recommendations for risk mitigation (integration). 
Subproject 4 (SP4) aims at integrating the results achieved in SP1, SP2 and SP3 in order to determine the overall flood risk. Therefore, subproject 4 aims to perform a risk analysis, to evaluate the current level of risk and to propose and discuss risk mitigation measures (Figure 6).

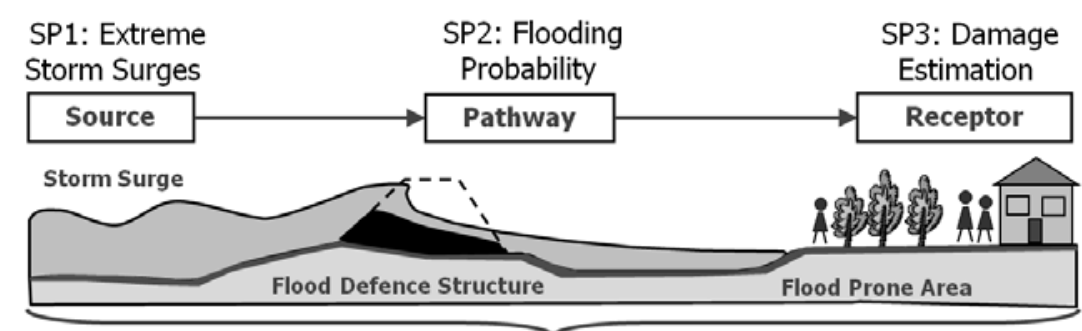

SP4: Integrated Risk Analysis

Figure 6. Source-pathway-receptor concept as used in XtremRisK.

Damages $D$ are classified into tangible and intangible damages (Figure 7) depending on whether or not the losses can directly be assessed in monetary values (Smith and Ward 1998). Tangible losses include damages to buildings and infrastructure, agricultural and industrial losses, costs related to evacuation, rescue operations and reconstruction, among others. Intangible losses include loss of life and health impacts, cultural losses, damages to the environment, and others (Dassanayake et al. 2010).

Furthermore, intangible losses are mainly categorized into two groups: social and environmental losses. Social losses are experienced by individuals, groups and the overall society, and mainly include loss of life, physical injuries and mental health impacts. Moreover, cultural losses are also considered under this category (Dassanayake et al. 2010). Environmental losses are damages to ecosystems, which will not be further discussed in this paper.

The analysis will be performed on the basis of storm surge scenarios under current (2010) and future (2100) climate conditions. Tangible damages will be estimated by flood depth-damage curves. The estimation of social and ecological losses is based on methods considering flood depth, flow velocity as well as flood warning parameters, e.g. as the estimation of fatalities and injuries. A methodology for the consideration of tangible and intangible damages within an integrated risk analysis is under development.

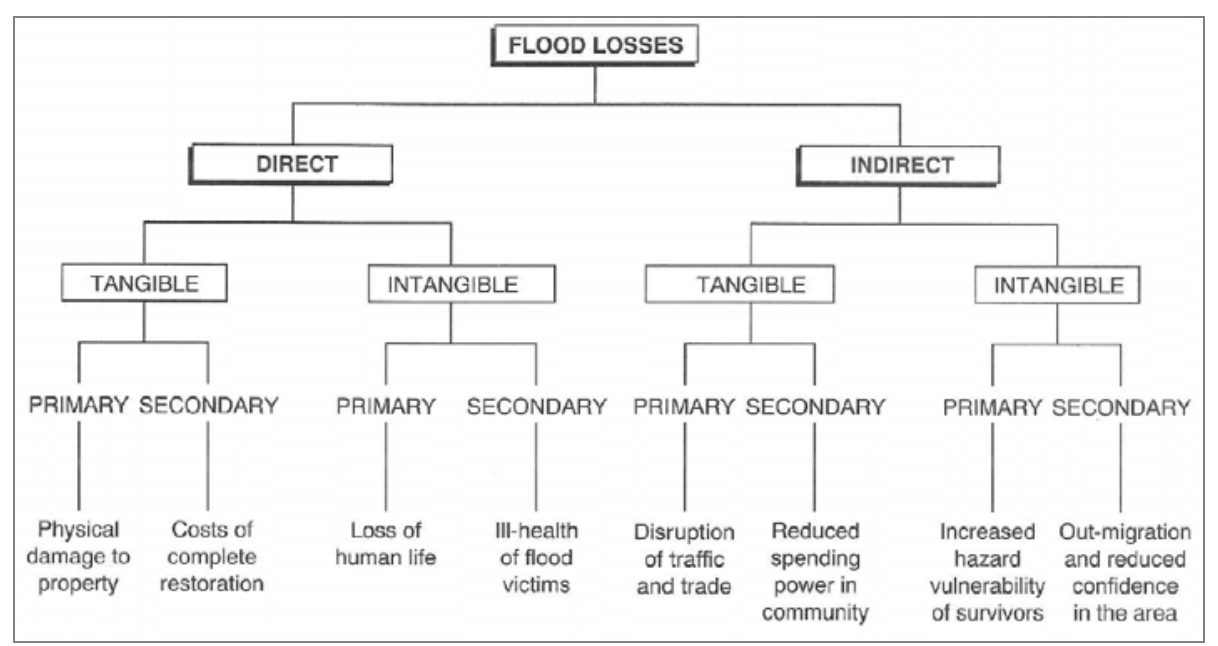

Figure 7. Categories of flood losses (Smith and Ward 1998). 


\section{FIRST RESULTS}

For the evaluation of coastal flood risks, knowledge of the characteristics of extreme storm surges is essential. Therefore, the objective of subproject 1 is to investigate extreme values of storm surge components, which are physically possible under present and future climate change conditions (Gönnert et al. 2010).

This also includes physically meaningful combinations of these parameters leading to storm surge scenarios for which the investigated study areas may suffer significant damages. As a first step, storm surges since 1901 and their constitutive components wind surge, tide and external surge have been analysed, such as the storm surge in 1976 (Figure 8).

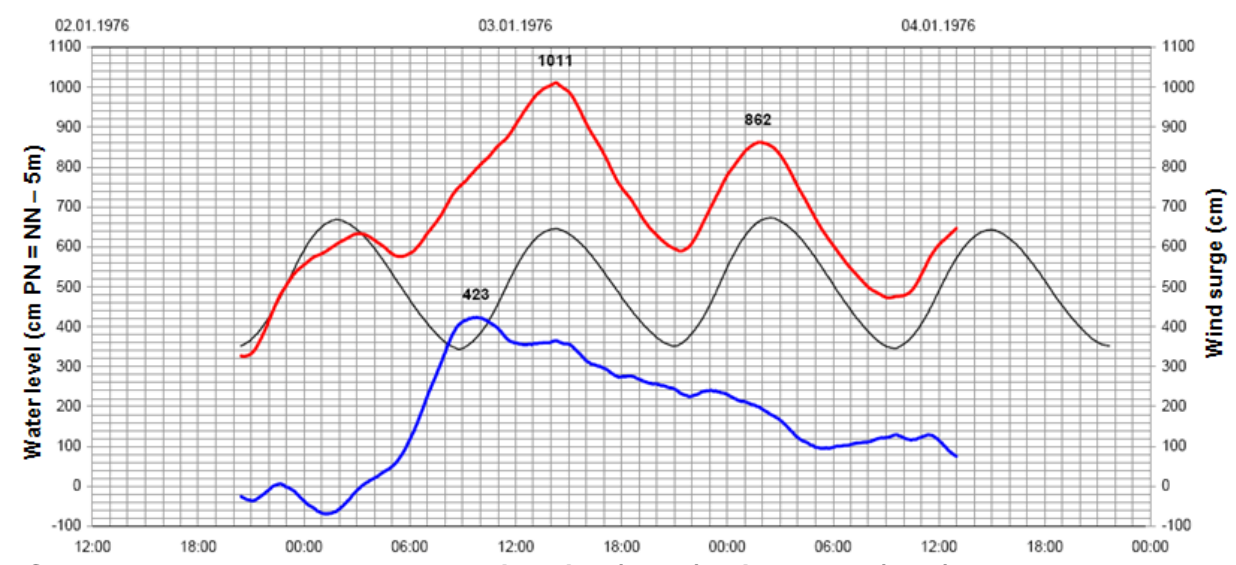

Figure 8. Storm surge components astronomical tide (black), wind surge (blue) and the observed water level (red) of the storm surge in 1976 at the Cuxhaven Gauge in the Elbe Estuary (Gönnert and Buß 2009).

The analysis has shown that those components interact nonlinearly (Gönnert et al. 2010). For example, the influence of the wind surge strongly depends on the astronomical tide. This result and further analysis will provide reliable storm surge curves and enables more precise prediction of maximum water levels for extreme storm surges. Moreover, this approach enables the generation of storm surge curves and not only maximum water levels. At present, the first synthetic, but even higher extreme storm surge HH_XR2010A based on the 1976 event has been developed by non-linear superposition of the highest event of each of the components wind surge, tide (including spring tide) and external surge (Figure 9). This storm surge would lead to a water level of approximately $8 \mathrm{~m} \mathrm{NN}$ in Hamburg.

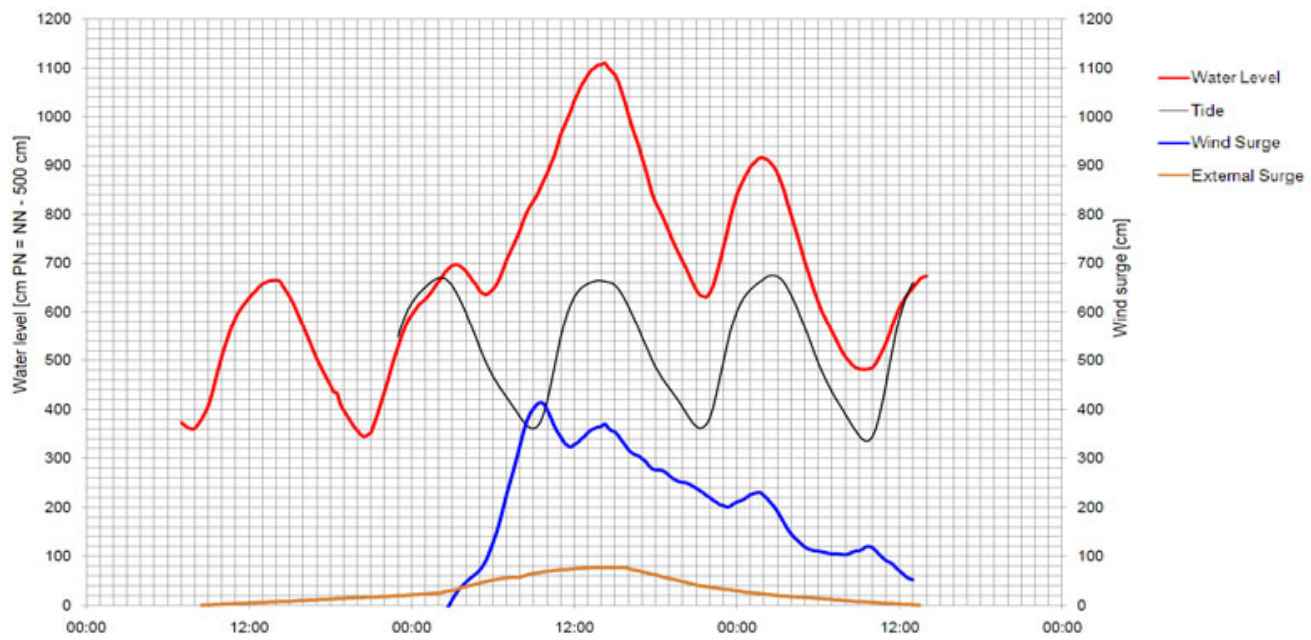

Figure 9. Generated synthetic storm surge HH_XR2010A and its components at the Cuxhaven Gauge in the Elbe Estuary based on the 1976 event (Sossidi et al. 2010, modified).

In addition to this analysis, a methodology based on multivariate statistics supported by the knowledge of the physics of the constitutive components and their possible superposition, as described above, has been developed in SP1. Hereby, effects such as changes in storm induced water levels and storm 
surge durations, among other effects, are taken into account. The associated uncertainties are explicitly considered by using a probabilistic approach.

For this analysis, tide gauge observations from 1900 until today have been digitized and analysed. For every storm surge curve, 25 parameters are determined, and for each parameter, an (extreme value) distribution is assigned. With these results, Monte-Carlo simulations for 1,000,000 events were performed in order to generate a sample of extreme storm surges (Figure 10) (Wahl et al. 2010). The methodology enables to assign joint probabilities for both, observed and synthetic storm surge events, considering the entire process of water levels during storm surge events. As a result of SP1, the calculated joint probabilities of storm surge events will be used for the calculation of failure probabilities of flood defence structures and the probability of flooding in subproject 2.

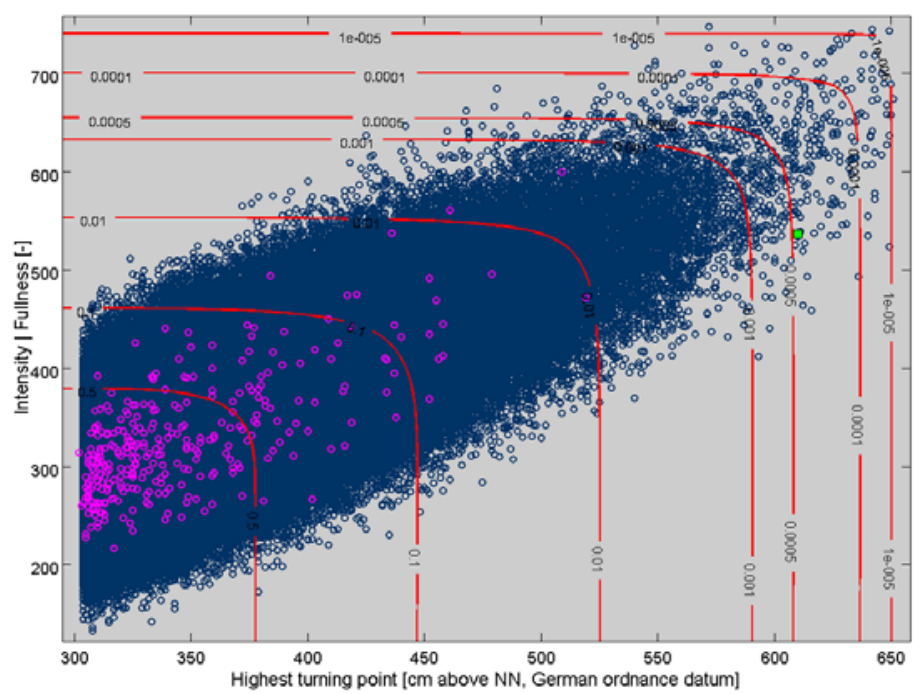

Figure 10. Synthetic storm surges by statistical simulations (blue) based on observed events (magenta) and the synthetic storm surge event HH_XR2010A (green) including the joint probability of each storm surge curve (red lines) (Wahl et al. 2010).

As shown in Figure 10, the parameters "highest turning point” (S) and “intensity/fullness” (F) are used, which are also considered for the statistical assessment of the simulation results. Figure 11 shows that the storm surge intensity is defined as the area between the storm surge curve and Normal Null (NN), which is approximately the mean sea level height. Thus, the combined consideration of the two mentioned parameters gives an approximation of the load (in terms of the energy input) for the coastal protection measures (Wahl et al. 2010).

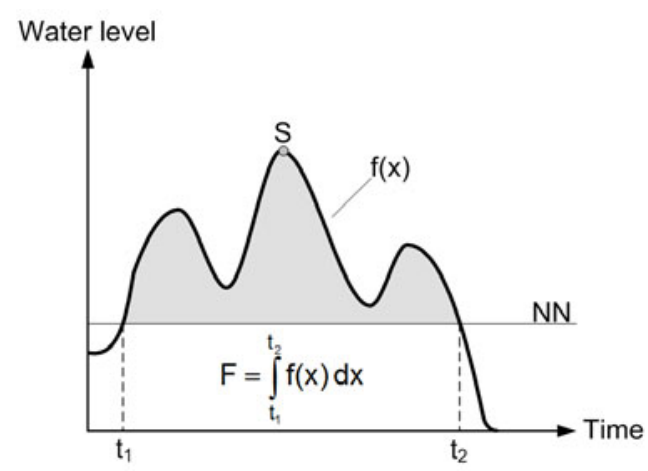

Figure 11. Definition of the parameter storm surge intensity (or fullness) (Wahl et al. 2010).

Subproject 2 uses the extreme storm surges developed in SP1 and determines the loading and the stability of all components of the flood defence system. The analysis of the failure of flood defence components requires a detailed appraisal of location, type and characteristics of defence structures.

For this purpose, an overview and detailed parameterisation of all flood defence structures were performed based on an intensive data collection in cooperation with the local flood defence authorities, in order to analyse and map the flood defence structures by using a GIS environment (Naulin et al. 2010). In addition, limit state equations for the failure modes of dikes, dunes and other types of struc- 
tures developed in former research projects such as FLOODsite (Allsop et al. 2007) and ProDeich (Kortenhaus 2003), among others, have been used to calculate the failure probabilities of the flood defence structures. For these calculations, more than 80 limit state equations are available (Naulin et al. 2010). In order to calculate failure probabilities of the flood defences, sections along the defence line with similar properties such as outline, geometric parameters, sea state parameters, geotechnical parameters, among others, were defined. The ultimate result is the failure probability of the flood protection systems (and thus the flooding probability) as the first component of flood risk (Figure 12) (Naulin et al. 2010).

Additionally, the initial conditions of the flood wave propagation, starting from the breach of the flood defences, the breach growth duration, the final breach width and depth and an outflow hydrograph at the breach location will be determined. The latter is needed by SP3 to simulate the flood inundation and related damages in the pilot site.

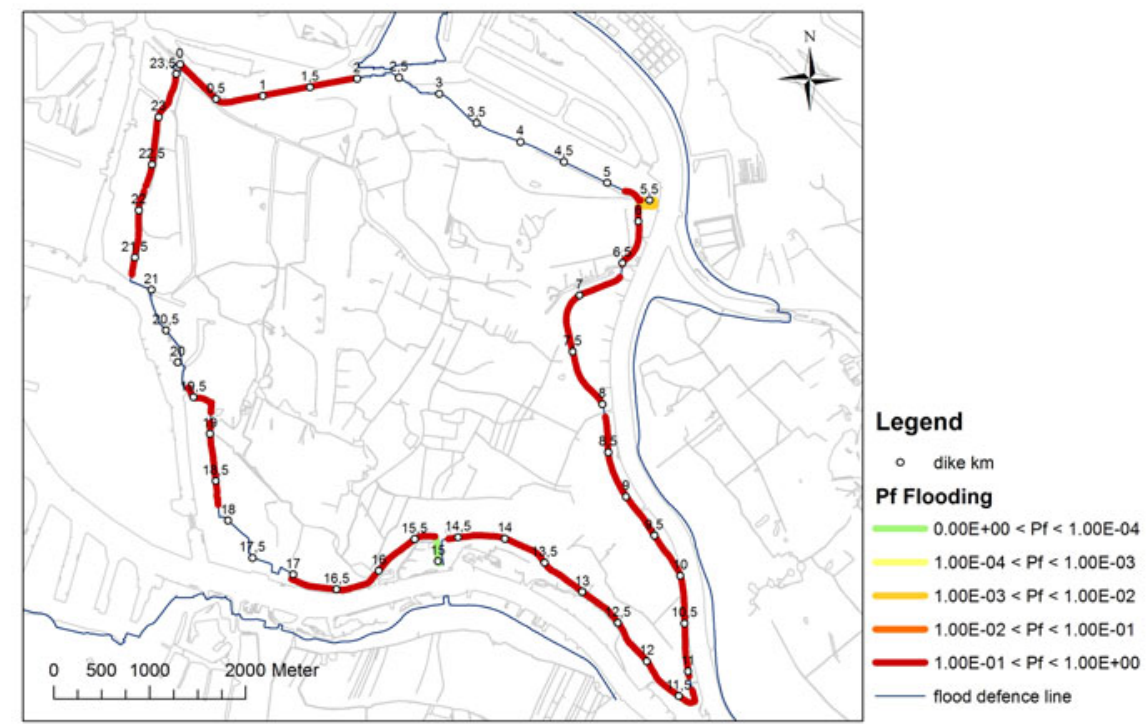

Figure 12. Sections of the flood defence line failure probabilities of the top event flooding for the synthetic storm surge HH_XR2010A with a maximum water level of $8.00 \mathrm{~m}$ (Naulin et al. 2010).

Within SP3, the expected direct and indirect economic losses (tangible losses) within the pilot site are assessed and evaluated. The analysis is performed by comprehensive means of scenario simulations. For this purpose, a cluster based meso-scale approach is used. Hereby, a micro scale analysis of damage costs for exemplary selected buildings is performed in order to refine the results. Based on this analysis, a group of buildings with similar properties is defined as one cluster.

A flood damage model has been developed to perform a physically based assessment of direct losses on the built environment. The assessment will be carried out using the software tool FloReTo (Manjolowich and Pasche 2010). For this analysis, 2D numerical flood simulations were performed using the open source platform Kalypso·RMA (see Schrage et al. 2009) (Figure 13). First results for the damage potential for the pilot site will be discussed in a forthcoming paper.

However, for the integrated flood risk analysis, intangible damages also have to be considered. Therefore, within subproject 4 (SP4) possible socio-economic (intangible) losses are analysed by using socio-economic evaluation methods in addition to the tangible losses in SP3. In HamburgWilhelmsburg, the analysis encompasses fatalities, injuries and psychological impacts. In the next section, the estimation of fatalities and injuries based on the methodology by Penning-Rowsell et al. (2005) is described (Figure 14).

The state-of-the-art in flood damage analysis mainly focuses on the evaluation of economic flood consequences (Messner and Meyer 2005). It has been found that social and ecological aspects of floodrelated vulnerabilities are neglected though they may represent a considerable contribution to the total losses (Green and Penning-Rowsell 1989). Integration of intangible and tangible damages is difficult since methods to assess these damages are not yet available or are very simplistic. Therefore, evaluation methods for the intangible losses have been critically reviewed and analysed (Dassanayake et al. 2010), but will not be part of this paper. 

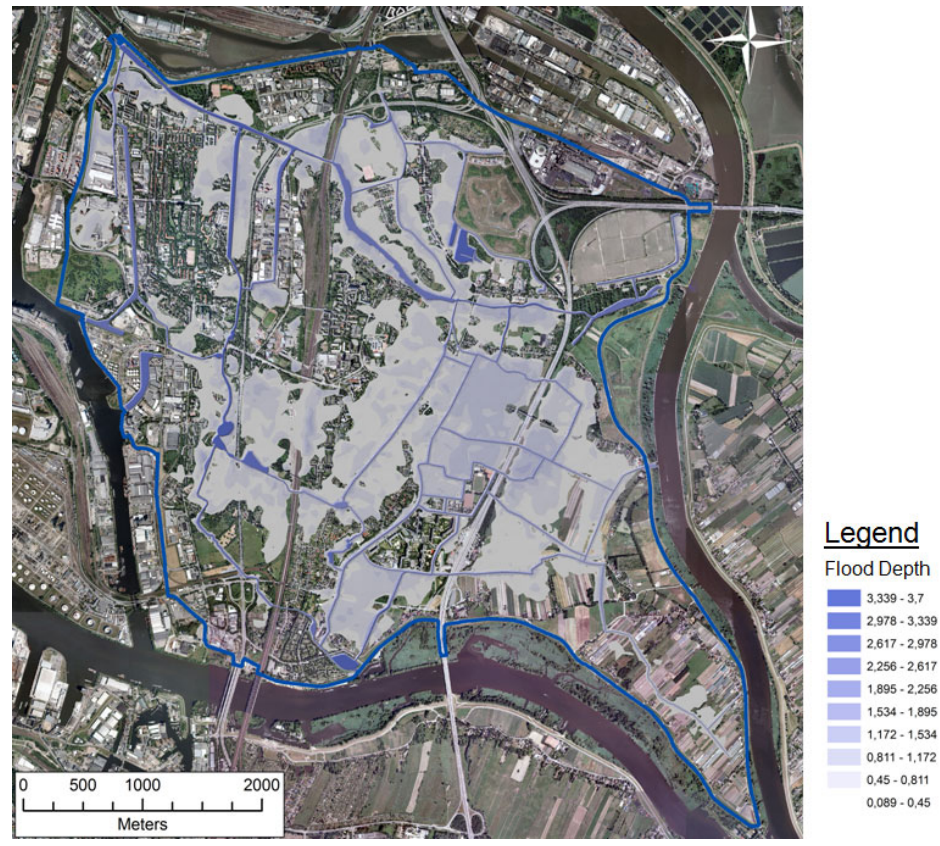

Figure 13. Simulated flooding in the Hamburg-Wilhelmsburg pilot site based on the synthetic storm surge HH_XR2010A with a maximum water level of $8 \mathrm{~m} \mathrm{NN}$ and 4 inflow locations.

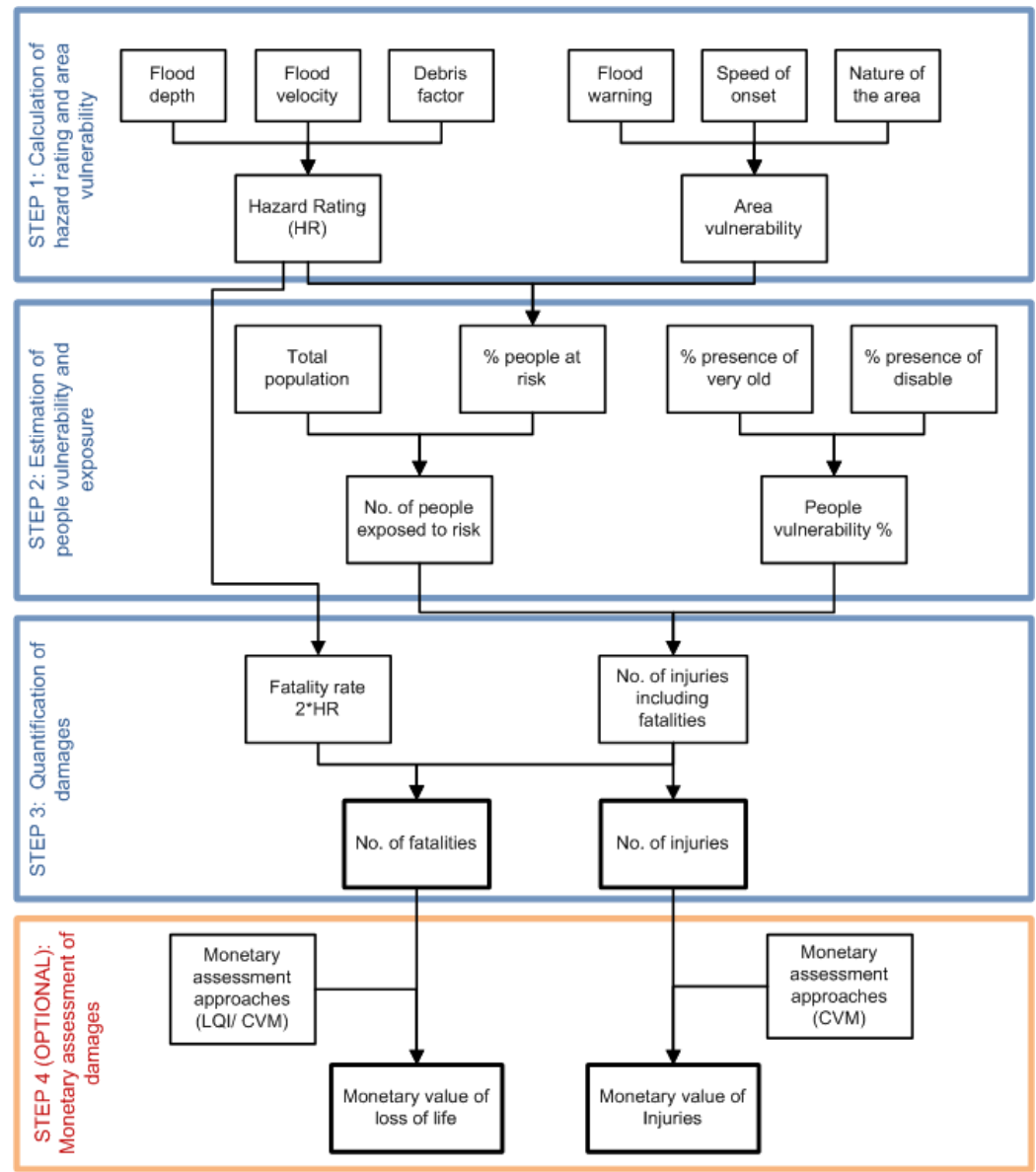

Figure 14. Methodology for the estimation of fatalities and injuries based on Penning-Rowsell et al. (2005) as proposed in Dassanayake et al. (2010). 
Since the results of subprojects SP1, SP2 and SP3 are preliminary, the analysis of societal consequences is just performed exemplarily in order to test the proposed methodology. All numbers and Figures given subsequently are hypothetic. The preliminary results are used in order to illustrate the applied methodology.

According to Penning-Rowsell et al. (2005), the number of deaths and injuries for a single flood event is estimated by $\mathrm{N}(\mathrm{I})=\mathrm{N} \cdot \mathrm{X} \cdot \mathrm{Y}$, "where $\mathrm{N}(\mathrm{I})$ is the number of death/injuries, $\mathrm{N}$ is the population within a floodplain, $\mathrm{X}$ is the proportion of the population exposed to a chance of suffering death/injury (for a given flood), and $\mathrm{Y}$ is the proportion of those at risk who will suffer death/injury."

It is assumed that $\mathrm{N}=500$ people are living close to a dike, which breaches suddenly. As a second step, under the assumption of a flood depth $d=2 \mathrm{~m}$, a typical velocity of $\mathrm{v}=2 \mathrm{~m} / \mathrm{s}$ and a debris factor of $\mathrm{DF}=2$ (likely), a hazard rating $\mathrm{HR}=\mathrm{d}(\mathrm{v}+1.5)+\mathrm{DF}$ is calculated as $\mathrm{HR}=9$.

As a third step, the area vulnerability (AV) as the sum of flood warning, speed of onset, and nature of area is calculated (Table 1 ) to be $\mathrm{AV}=5$.

\begin{tabular}{|c|c|c|c|}
\hline Parameter & Flood Warning & Speed of onset & Nature of Area \\
\hline Description & $\begin{array}{l}\text { flood warning } \\
\text { system present } \\
\text { but limited }\end{array}$ & $\begin{array}{l}\text { onset of flooding } \\
\text { is gradual }\end{array}$ & $\begin{array}{l}\text { multi-storey } \\
\text { apartments }\end{array}$ \\
\hline Score & 2 & 2 & 1 \\
\hline
\end{tabular}

As a result, the number of people at risk $\mathrm{X}=\mathrm{HR} \cdot \mathrm{AV}$ is $\mathrm{X}=45 \%$. Based on 500 peoples living close to the dike, $45 \%$ of them are assumed to be at risk, i.e. 225 people. The people vulnerability is estimated by two parameters: the presence of people older than 75 years $\left(\mathrm{P}_{1}\right)$ and the presence of disabled and long term sick people $\left(\mathrm{P}_{2}\right)$. While the first is scored as $\mathrm{P}_{1}=10 \%$ (well below national average), the latter is rated as $\mathrm{P}_{2}=25 \%$ (around national average) (cf. Statistik Nord 2009). Hence, $\mathrm{Y}=\mathrm{P}_{1}+\mathrm{P}_{2}$ is calculated as $\mathrm{Y}=35 \%$.

Based on the result of $\mathrm{X}=225$ people at risk, the number of injuries including loss of life $\mathrm{N}(\mathrm{I})=\mathrm{X} \cdot \mathrm{Y}$ is calculated as $\mathrm{N}(\mathrm{I})=78$. With $\mathrm{FR}=2 \cdot \mathrm{HR}, \mathrm{F}=\mathrm{N}(\mathrm{I}) \cdot \mathrm{FR}$ can be calculated to be $\mathrm{F}=14$ fatalities.

The results are found to mainly depend on the area vulnerability scores. In case of a higher rating of the area vulnerability, an increased number of people at risk is calculated (Table 2).

\begin{tabular}{|c|c|c|c|}
\hline Parameter & Flood Warning & Speed of onset & Nature of Area \\
\hline Description & $\begin{array}{l}\text { no flood warning } \\
\text { system }\end{array}$ & rapid flooding & $\begin{array}{l}\text { typical residential } \\
\text { areas }\end{array}$ \\
\hline Score & 3 & 3 & 2 \\
\hline
\end{tabular}

Hence, the area vulnerability results as $\mathrm{AV}=5$. Moreover, the number of people at risk $\mathrm{X}$ increases to $\mathrm{X}=72 \%$, i.e. 360 people. Assuming the same people vulnerability $\mathrm{Y}=35 \%$, the number of injuries including loss of life $\mathrm{N}(\mathrm{I})$ is calculated as $\mathrm{N}(\mathrm{I})=126$. As a result, $\mathrm{F}=22$ fatalities are estimated.

With respect to the pilot site Hamburg-Wilhelmsburg, if a storm surge with a critical water level in Hamburg with more than $7.30 \mathrm{~m} \mathrm{NN}$ is expected, evacuation measures have to be initiated. For residential areas outside the dike ring, the critical level for evacuation is $6.50 \mathrm{~m} \mathrm{NN}$ (Behörde $\mathrm{f}$. Inneres 2010).

As a next step, tangible and intangible losses must be integrated into a risk analysis. The aim is to perform an analysis considering both, tangible and intangible damages in order to calculate the overall risk and to develop optimal mitigation strategies for different scenarios. Therefore, SP4 integrates all results from all subprojects and aims at performing a full flood risk analysis for the pilot sites based on the source-pathway-receptor concept as described above. For this purpose, several approaches have been reviewed in order to find an optimal strategy for the integration of tangible and intangible damages within an integrated risk analysis (see Dassanayake et al. 2010).

As a first possibility, the presentation of damages and losses within damage categories, further termed as categorisation, has been examined. For this purpose, similar damages such as societal losses are grouped as one category. The main advantage is that optimal mitigation measures for each damage 
category can be specified. However, this approach is not a real integration, even though a full flood risk analysis is performed. Tangible and intangible losses are considered, but not expressed in the same terms within one risk analysis, since every risk is calculated separately and in different units. Furthermore, mitigation strategies for one damage category influence other categories as well. These aspects cannot be considered properly by using the categorisation approach.

The second approach which has been examined is the Multi-Attribute-Utility (MAUT) approach. This approach was tested and proposed for integrated risk analysis in the European Research Project FLOODsite (Meyer et al. 2007). The MAUT approach is based on the ranking between different options by the consideration of their utility functions. Utility functions are favoured as they express the economic behaviour of individuals or the society. Utility functions enable the weighting, balancing, and ranking of different options, such as mitigation strategies, within an integrated risk analysis. The aim is to maximise the sum of the utilities of all options. The following steps are required for the analysis within the MAUT approach (Meyer et al. 2007):

1. Standardise the criteria scores to values (or utilities) between 0 and 1 .

2. Calculate weighted values for each criterion by multiplying the standardised value with its weight.

3. Calculate the overall value (utility) for each alternative by summing the weighted values (utilities) of each criterion.

4. Rank alternatives according to their aggregate value (utility).

The main advantage of the MAUT approach is the possibility to merge all weighted utilities into one mathematical model. As a result, an optimisation of all utilities will be performed while different strategies and preferences of prospective end-users can be considered. Finally, an optimal mitigation strategy can be identified. On the other hand, the estimation of utility functions might need an intensive economic analysis and survey. However, utility cannot be measured or observed directly. Instead, from the behaviour of individuals or the society, a utility must be derived under the assumption of a perfect economic market (Hanley and Spash 2003).

As a third approach, the monetary assessment of tangible and intangible losses has been examined. In this approach, all losses are considered within a cost-benefit analysis. Therefore, intangible losses, which are usually not expressed in monetary terms, have to be estimated by using socio-economic evaluation methods such as Contingent Valuation or Hedonic Price Method, among others. An advantage of this approach is the possibility to calculate the risk $R_{f}$ for each damage category separately. Furthermore, cost-benefit ratios can be calculated for several mitigation strategies. However, the monetary assessment of intangible goods, such as human beings and the environment, is often opposed due to ethical constraints. Moreover, intangible losses are not adequately reflected in a cost-benefit analysis related to their importance. Hence, weighting factors for intangible goods must be implemented (RPA 2004).

\section{FUTURE PROSPECTS}

As described above, the integrated risk analysis described in this paper is based on intermediate results only. Therefore, all results have to be verified and completed. The aforementioned approaches will be further tested. Later on, the risk analysis will be performed on the basis of scenarios under current and future climate conditions. All results will be compared to each other in order to find an optimal approach for the integration of tangible and intangible losses as well as for the full flood risk analysis. In addition, the approach must be suitable for decision making with respect to different mitigation strategies and multi-criteria optimisation.

Within subproject 1, the number of Monte-Carlo simulations for the synthetic storm surge generator will be further increased in order to improve the statistical analysis. At the moment, wave conditions are not taken into account. Hence, in the next step of XtremRisK, the models will be extended to consider wave conditions additionally (Wahl et al. 2010).

In subproject 2, proposed methods of reliability analysis and breach modelling will be further applied to the costal defence system at the Hamburg-Wilhelmsburg pilot site. Moreover, it is intended to update and further develop missing limit state equations and fault trees for failure mechanisms or structures not yet considered (Naulin et al. 2010).

In subproject 3 , the analysis of tangible damages will be extended to further damage categories such as industry, goods, private property and infrastructure, among others. Furthermore, indirect damages are estimated using an economic input-output-model.

Within subproject 4, the application of the integration approaches described above will be tested in detail. Hereby, further intangible losses such as environmental and cultural losses will be considered. The analysis will be first applied at the Hamburg-Wilhelmsburg pilot site in order to propose flood risk 
mitigation measures. Moreover, it is planned to perform a systematic uncertainty and sensitivity analysis to investigate the relative importance of the input parameters and to obtain practical implications for the management measures which will be developed.

\section{SUMMARY}

In this paper, the German joint research project 'XtremRisK' (Extreme Storm Surges at Open Coasts and Estuarine Areas - Risk Assessment and Mitigation under Climate Change Aspects) is presented. XtremRisK follows the source-pathway-receptor concept and consists of four subprojects.

Subproject 1 (SP1) analyses the risk source, i.e. the statistics and physics of extreme storm surges. The developed methodology now enables the generation of synthetic extreme storm surges and the consideration of the whole storm surge curve, not only the maximum water level.

Subproject 2 (SP2) investigates the risk pathways to estimate the probability of flooding. Hereby, different failure modes of the various flood protection structures are analysed by means of fault tree analysis. For the flood protection system, a probability of flooding will be determined. In addition, dike breaching, breach growth development, the final breach width and depth are analysed and used as an input for the inundation model in subproject 3.

Subproject 3 (SP3) analyses the direct and indirect tangible damages within the pilot sites. Therefore, an inundation model was developed based on Kalypso·RMA. Damages of residential buildings are estimated by using a cluster-based approach.

Subproject 4 (SP4) integrates the results obtained in SP1, SP2 and SP3. In addition, intangible damages are estimated using socio-economic evaluation methods. The results will be integrated within a full flood risk analysis. For this purpose, integration approaches have been discussed with respect to their advantages and limitations which will eventually lead to a final and improved methodology to integrate tangible and intangible damages.

The prospective results will help to better understand the relationship between extreme storm surges and the related flood risks. Furthermore, the developed methods to quantify storm surge induced risks will be applied to the pilot sites of Hamburg and Sylt Island. These results may improve the ability of responsible agencies and end-users to better mitigate potential damages by extreme storm surges.

Further information about the XtremRisK project and intermediate results are also presented at the project website under www.xtremrisk.de.

\section{ACKNOWLEDGEMENTS}

This study within the joint research project XtremRisK is funded by the German Federal Ministry of Education and Research BMBF (Project. No. 03 F 0483 A).

Moreover, the collaboration and the provision of data by the Cooperative and Consulting Partners of the project such as LKN-SH (Schleswig-Holstein Agency for Coastal Defence, National Park und Marine Conservation), HPA Hamburg (Hamburg Port Authority) and LSBG Hamburg (Agency of Roads, Bridges and Waters, Hamburg) are gratefully acknowledged.

\section{REFERENCES}

Allsop, N.W.H., F. Buijs, M.W. Morris, R. Hassan, M.J. Young, N. Doorn, J.W. Van der Meer, A. Kortenhaus, P.H.A.J.M. Van Gelder, M. Dyer, M. Redaelli, P.J. Visser, R. Bettess, and D. Lesniewska, 2007. Failure mechanisms for flood defence structures. FLOODsite - Integrated Flood Risk Assessment and Management Methodologies. Res.-Report, T04-05-01, Task 4, 150 p.

Behörde f. Inneres, 2010. Storm Surge Flyer (in German). Available at http://www.hamburg.de/contentblob/562890/data/sturmflutmerkblatt-wilhelmsburg.pdf

Bütow, H., 1962. Die große Flut in Hamburg : Eine Chronik der Katastrophe vom Februar 1962. Freie und Hansestadt Hamburg, Schulbehörde, Hamburg.

Dassanayake, D.R., A. Burzel, A. Kortenhaus, and H. Oumeraci, 2010. Framework and Methods for the Evaluation of Intangible Losses and their Integration in Coastal Flood Risk Analysis. XtremRisK Progress Report. Leichtweiß-Institute for Hydraulic Engineering and Water Resources, Technische Universität Braunschweig.

Green, C.H., and E.C. Penning-Rowsell, 1989. Flooding and the Quantification of 'Intangibles'. IWEM: Annual Symposium Paper No. 8. pp 27-30.

Gönnert, G., and T. Buß, 2009: Sturmfluten zur Bemessung von Hochwasserschutzanlagen. Freie und Hansestadt Hamburg, Landesbetrieb Straßen, Brücken und Gewässer, Hamburg, Germany

Gönnert, G., B. Gerkensmeier, J.-M. Müller, K.Sossidi, and S. Thumm, 2010. About the hydrodynamic interaction between the storm surge constituents wind surge, astronomical tide and exter- 
nal surge (in German). XtremRisK Progress Report. Agency of Roads, Bridges and Waters, Hamburg, Germany.

Hanley, N., and C.L. Spash. 2003. Cost-Benefit analysis and the environment. Edward Elgar Publishing Ltd., Cheltenham [u.a.].

IPCC, 2007. Climate change 2007: WG II: Impacts, Adaptation and Vulnerability, Chap. 6. Coastal systems and low lying areas. Intergovernmental Panel on Climate Change (IPCC), Cambridge University Press.

Kortenhaus, A., 2003. Probabilistische Methoden für Nordseedeiche. Ph.D. thesis, Dissertation, Fachbereich Bauingenieurwesen, Leichweiss-Institute for Hydraulic Engineering and Water Ressources, Technische Universität Braunschweig, Braunschweig, Germany, 154 p.

Manojlovic N., and E. Pasche, 2010. Theory and Technology to Improve Stakeholder Participation in the Development of Flood Resilient Cities, Proc. Int. 21st IAPS Conference on Vulnerability, Risk and Complexity: Impacts of Global Change on Human Habitats, Leipzig, Germany

MEA, 2005. Ecosystems and Human Well-being, A framework for assessment. Millenium Ecosystem Assessment Series, Island Press, Washington D.C.

Messner, F., and V. Meyer, 2005. Flood damage, vulnerability and risk perception - challenges for flood damage research. UFZ Discussion Papers. Department of Economics, Leipzig.

Meyer, V., D. Haase, and S. Scheuer, 2007. GIS-based Multicriteria Analysis as Decision Support in Flood Risk Management, FLOODsite Project Report, HR Wallingford, UK.

Naulin, M., A. Kortenhaus, and H. Oumeraci, 2010. Failure Probability of Flood Defence Structures/ Systems in Risk Analysis for Extreme Storm Surges. Proceedings 32nd International Conference Costal Engineering (ICCE), Shanghai, China.

Oumeraci, H., 2004. Sustainable coastal flood defences: scientific and modelling challenges towards an integrated risk-based design concept. Proc. First IMA International Conference on Flood Risk Assessment, IMA - Institute of Mathematics and its Applications, Session 1, Bath, UK, pp. 9-24.

Oumeraci, H., J. Jensen, G. Gönnert, E. Pasche, A. Kortenhaus, M. Naulin, T. Wahl, S. Thumm, G. Ujeyl, I. Gershovich, and A. Burzel, 2009. Flood risk analysis for a megacity: The German XtremRisK project, Proc. Conference on Road Map towards a Flood Resilient Urban Environment, Paris, France, 8 p.

Penning-Rowsell, E., P. Floyd, D. Ramsbottom, and S. Surendran, 2005. Estimating Injury and Loss of Life in Floods: A Deterministic Framework. Natural Hazards (36) pp 43-64.

Pietsch, G., 1962. Sturmflut 1962 in Hamburg-Wilhelmsburg. Wikimedia Commons, licensed under GNU-licence for free documentation

RPA - Risk and Policy Analysts Ltd, 2004. Evaluating a multi-criteria analysis (MCA) methodology for application to flood management and coastal defence appraisals. R\&D Project Record FD2013/PR1, DEFRA, UK.

Schrage, N., D. Anatanaskovic, T. Jung, and E. Pasche, 2009. KALYPSO - An Open Source Software Tool for Flood Studies in Rivers. In: Proceedings of the 8th International Conference on Hydroinformatics. Concepción, Chile, Jan. 2009

Schwartz, M., 2005. Encyclopedia of Coastal Science. Dordrecht, Springer

Smith, K., R. and Ward, 1998. Floods: Physical processes and human impacts. John Wiley and Sons, Chichester, UK.

Sossidi, K., G. Gönnert, and B. Gerkensmeier, 2010. The risk and calculation of extreme storm surges due to climate change. Presentation Storm Surges Congress 2010 - Risk and Management of current and future Storm Surges, Hamburg, Germany.

Statistik Nord, 2009. Statistical data for Hamburg. Available at http://www.statistik-nord.de/uploads/ tx_standocuments/StadtteilprofileInstantAtlasDownload.xls, accessed: June 2010

Wahl, T., J. Jensen, and C. Mudersbach, 2010. A Multivariate Statistical Model for Advanced Storm Surge Analyses in the North Sea, Proceedings 32nd International Conference Costal Engineering (ICCE), Shanghai, China.

Woth, K., 2005. Regionalization of global climate change scenarios: An ensemble study of possible changes in the North Sea storm surge statistics, $\mathrm{PhD}$ Thesis prepared within the International Max Planck Research School on Earth System Modelling, Hamburg, Germany. 